\title{
STUDIA I MATERIAŁY
}

DOI: 10.18276/SIP.2018.52/2-28

\author{
Anna Bielawa* \\ Uniwersytet Szczeciński
}

\section{THE APPLICATION OF DESIGN THINKING IN SMALL AND MEDIUM ENTERPRISES}

\begin{abstract}
Design thinking is the modern method of creating innovative solutions used by large and well-known companies around the world. It could be a solution for smaller business entities to encourage them to intensify the undertaken innovative actions and permanent development. The research goal was to determine whether project thinking is also used in the sector of small and medium enterprises, and if so, what are the scope and possibilities of its application. The research was based on the analysis of Polish and foreign literature and on the results of researchwhich was carried out by foreign reasercher. It was found that business entities operating in the SME sector implement the concept of design thinking, and through the use of creativity and design thinking techniques can create innovative solutions.
\end{abstract}

Keywords: innovation, SMEs, design thinking

JEL code: 031 


\section{Introduction}

Every enterprise, regardless of its size, which wants to function within the immensely turbulent and competitive environment, is forced to constantly perfect itself and search for innovative ideas resulting in the company's development. As it is known, the most innovative enterprises are those which are large and possess more capabilities to efficiently implement innovations, resulting from their potential concerning finances, human resources, and assets, as well as technical knowledge and market information (Poznańska, 1998, 40-41).

A solution for smaller business entities, which will encourage them to intensify the undertaken innovative actions and a permanent development, may consist in the idea of creating innovations based on the method of design work, meaning design thinking.

In Poland, mainly large enterprises or institutions use design thinking. Meanwhile, its application in the SME sector would allow for the creation of many innovative solutions in the field of products, processes, organization, marketing. It does not needlarge financial expenses, which are a significant problem in the development of SME, but it requires a total change in perception of the problem, rejection of existing solutions, focus on the customer and design solutions that are ideally suited to his needs and expectations. The concept requires absolutely cooperation and teamwork, which is easily obtained in a small or medium enterprises and which improves communication in the company, information flow, increases the efficiency of undertaken activities.

That is why the goal of this article is to present the essence and meaning of the concept as well as to determine whether design thinking is also used in the sector of small and medium size enterprises, and if so then what are the scopes and possibilities of its application.The research is based on the analysis of Polish and foreign literature and on the results of research, which was made by foreign researcher.

\section{The essence and meaning of design thinking}

The concept of design thinking constitutes a culture, a model of thinking, and a method. It allows to stimulate innovativeness and creativity within an enterprise, 
as well as to impact the formation or perfection of products, services, and processes by working in multidisciplinary teams. It is one of the new methods concerning approaching innovativeness - a demand concept, in which the main goal consists in an identification of the client's needs, and the enterprise itself constitutes the place where the innovation is being created.

Taking advantage of the method comes down to focusing on the product or an activity of a strategic character. A product approach includes actions related to: observation (determining the hidden and revealed needs), identifying the needs of clients (for example through a brainstorm), determining prototypes, alternative solutions, as well as their multiple tests, and implementing the design. Whereas, taking advantage of design thinking in the strategic approach, assumes developing new work methods (Understand..., 2006, p. 13).

Design thinking is defined in various ways. It is generally understood as "taking advantage of the designer's sensitivity and methods of solving problems, (...) a methodology of solving problems" (Lockwood, 2010, p. xi). It is regarded as a "discipline which takes advantage of common sense and the methods of designers, in order to satisfy the needs of people through what is technologically possible, as well as what can a reasonable business strategy transform into a value for the client and a market chance (Brown, 2008, p. 86).

The approach to design thinking is currently changing. It is now not only a method of designing the product and process, but a key factor of a company's strategy (Bucolo, Matthews, 2010; Carlopio, 2009). Design thinking used for the purposes of designing a business strategy and transformation, is sometimes described as integrative thinking (Cooper, Junginger, Lockwood 2010; Martin, 2009). This approach focuses on innovations and business changes, discovering unmet needs and capabilities, as well as creating new visions and scenarios(Matthews, Wrigley, 2017, p. 43).

The basic element of design thinking is the ability to acquire new knowledge, thanks to which it is possible to take advantage of the well known techniques and tools in a new and original manner (Bucolo, Matthews, 2010). This becomes possible thanks to combining designing tools with organizational innovations which identify the strategic value of design thinking (Matthews, Wrigley, 2017, p. 43). Therefore, it is a process of innovation focused on the person, which puts much emphasis on observation, cooperation, learning, visualizing the idea, and prototyping, at the same 
time taking into consideration the business perspective (Jak wykorzystać..., 2015, p. 12.)

\section{The stages and methods of executing ideas in an organization}

The concept of design thinking is significantly flexible, that is why it is very difficult to define the clear functioning boundaries and guidelines when basing on it. Whereas, the sole process of design thinking is constant and consists of five stages (Rudkin, Ingle, 2015, pp. 18-19), which have been presented in Figure1.

Figure 1. Stages of design thinking

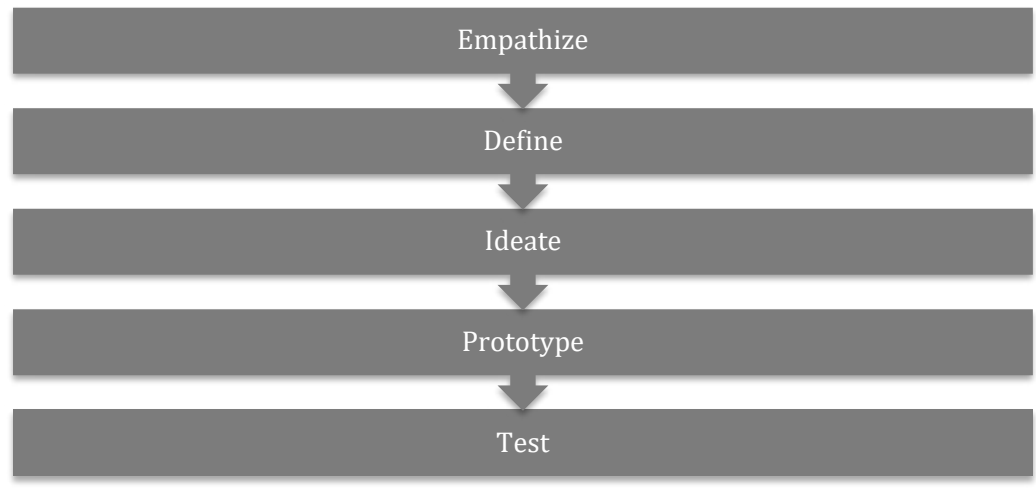

Source: Rudkin Ingle (2015)

Empathization is also referred to as the cognitive stage during which we learn the problem by observing the participants. In other words, during this stage it is necessary to look at the problem from the point of view of the consumer thanks to which it is possible to distinguish hidden needs and motivations which impact the choices people make. During the second stage, already possessing the needed information as well as the qualitative and quantitative data gathered during the previous stage, the problem is being defined along with the reason why should it be handled. The next step - ideation, also referred to as generating ideas, consists in searching for all of the possible solutions to the analyzed problem, with the use of for example a brainstorm. During the fourth stage we overview the list of the possessed possible solutions, then we select two or three of them in order to execute their 
prototypes. The final stage consists in presenting the prototypes to their potential users in order to confirm or reject the generated solutions. Therefore, it is important for the testing to be carried out in such conditions in which the product will be used. Executing specific stages of the concept requires understanding and following the rules of design thinking (Plattner, Meinel, Leifer, 2011, pp. 14-15) which include:

1. The principle concerning people: all design actions are social in their nature, which is why implementing solutions should strive to satisfy the needs of people.

2. The principle of ambiguity - leaving limitations and creating conditions for experimenting on the threshold between knowledge and imagination. Solutions which initially seem incorrect should be the ones looked for.

3. The principle of redesigning - all actions are redesigned. Basing on historic solutions an attempt should be made to design future technical and social conditions in order to analyze and solve the problem as best as possible.

4. The principle of tangibility - turning ideas into reality by visualizing them and prototyping improves the communication between the members of the design team.

Design thinking may be implemented into the organizational culture in the following manners (Juninger, 2009, pp. 23-29):

- peripheral, in which design thinking has no set place within the organization and is executed "on demand" with the help of external innovation consultants whose task is to provide support concerning designing when needed,

- selective, where design thinking is executed only in some areas of an organization, for example in the marketing or R\&D departments,

- core, in which design thinking plays the main role in undertaking strategic decisions. The person taking advantage of it is the leader, and that is why it is connected with the company's general strategy,

- internal, where design thinking constitutes a set practice and manner of thinking; it constitutes an integral part of all company aspects and is used for revealing and discovering solutions for all types of organizational problems, in other words, design thinking becomes a part of the culture. 


\section{Design thinking in the SME sector}

Until recently design thinking was reserved only for large enterprises. Currently the concept is more and more often taken advantage of by small and medium size business entities, which is also confirmed by the results of research which have been carried out by researchers from Germany. The research (Schmiedgen, Rhinow, Köppen, Meinel, 2015) has been carried out on a group of 235 respondents consisting of managers (51.1\%) and members of design thinking groups from enterprises all over the world. More than 84 of them came from the EMEA group, meaning countries from Europe, the Middle East, and Africa. Most of the respondents came from Germany.

Taking into consideration the size of the enterprises which participated in the research, MSE sector enterprises constituted 64\% (micro and small entities constituted 52\%, while medium size ones $12 \%$ ), and large ones $36 \%$ (Schmiedgen et. al. 2015, p. 17). Thus, a conclusion that the concept is carried out in enterprises regardless of their size.

It has been determined that the idea of design thinking is used mostly by companies classified in the $\mathrm{J}$ section of the Polish Business Classification, meaning Information and Communication (mainly IT companies), section S - Other Service Businesses (for example offering design thinking services), and the $\mathrm{P}$ section Education (Schmiedgen et. al. 2015, p. 20).

According to most respondents (72.3\%) the design know-how is located and used only in specialized organizational units, primarily in the $R \& D$ and marketing departments. By taking advantage of the concept selectively in reference only to specific departments it is impossible to create a system which would allow to take full advantage of the possessed organizational potential, and increase the efficiency of own actions thanks to tools and practices (Schmiedgen et. al. 2015, p. 52).

An incorrect diffusion and implementation within the organization also constitutes one of the reasons for failure in terms of implementing the concept. A different reason is the lack of engagement from the management. The lack of execution continuity may also result from an initial assumption that the method is used once (Schmiedgen et. al. 2015, p. 106).

Enterprises which decide to take advantage of design thinking expect that the concept will have an impact on (Schmiedgen et. al. 2015, pp. 58-93): 
- providing services which intend to help the client to find a better solution or an internal change,

- the creation of a new or perfected product/service,

- the improvement of cooperation and sharing knowledge;

- an increase in terms of empathy, meaning a better understanding of the client's needs,

- improving the internal business processes and the organization's structure,

- the creation of marketing innovations,

- developing better forms of teaching and training,

- increasing creativity within the teams,

- an increase in the client commitment and co-creating innovations,

- improving the designing of services,

- the formation of new business models and strategies for entering the market,

- taking advantage of it as a tool in the process of recruitment,

- more efficient work when executing tasks,

- generating demand,

- improving the innovation process,

- perfecting research results.

Unfortunately a product or service innovation directed at a client is often not the main reason for taking advantage of it. Many organizations expect improving internal processes and cultural changes in terms of teams and actions (Schmiedgen, Rhinow, Köppen, Meinel, 2015, p. 9).

Nevertheless, as presented in Figure 2 as much as $69 \%$ of respondents have noticed an increase in the efficiency of innovative processes in design thinking, and $71 \%$ the effects in the form of improving work culture. 
Figure. 2. The impact of design thinking in organization

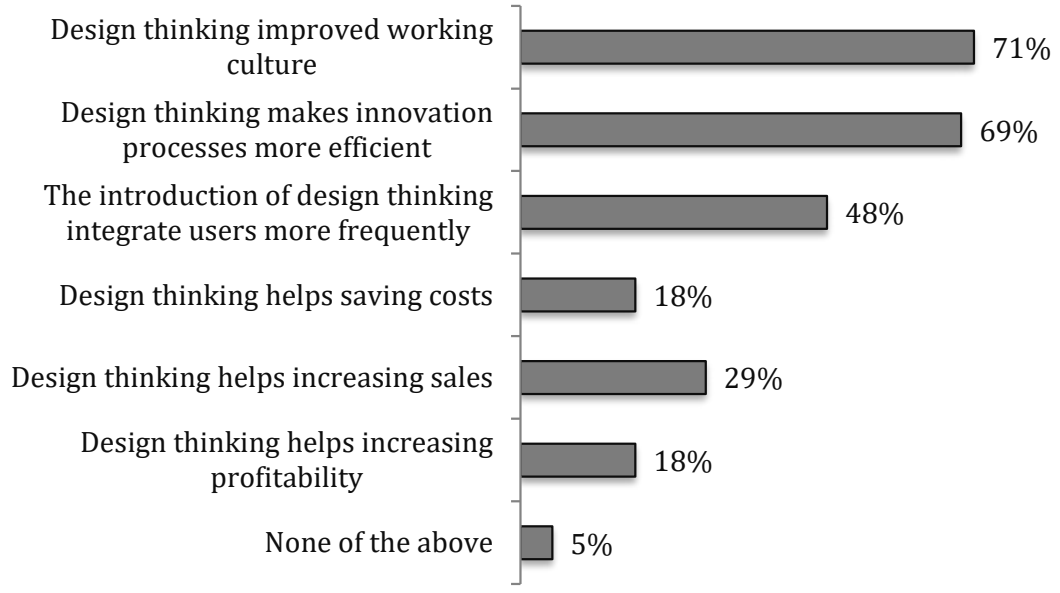

Source: Schmiedgen et al. (2015), p.101.

\section{The possibilities to take advantage of design thinking in small and medium size enterprises}

Only large companies such as Apple, or Procter \& Gamble initially used design thinking. Currently, this method has found its aficionados within the sector of small and medium size companies, as it is shown by the research presented in this paper. That is because this concept may be used to carry out research, designing a business strategy, customer experience, digital customer service, designing a website, designing a service and the process of providing it, marketing, or change (Rudkin Ingle, 2015).

As it has been mentioned, when it comes to design thinking one of the possibilities it provides is to carry out research, which in terms of this concept is characterized by the following elements (Rudkin Ingle, 2015, pp. 34-48):

1. The research take on the form of questions asked in various ways, and answers to those questions.

2. Both quantitative and qualitative researches are important. The basic quantitative research consists in a survey, although information may also be 
acquired by for example analyzing websites (access, clickability, number of visitors). Whereas, focus groups, interviews, client observations, and their interception constitute significant qualitative methods.

3. The research serves 4 roles: stabilizer, archeologist, interpreter, and the devil's advocate.

- The role of the stabilizer comes down to gathering measurable information concerning the market, competition, data, or the clients' demographic features. An example of a stabilizer is a survey. A survey research constitutes one of the methods of gathering data from primary sources. Survey research can be divided into direct and indirect. Direct survey research consists in gathering information during a direct contact of the researcher with an individual person or a group. Whereas, indirect survey methods consist in acquiring interesting information with the use of questions asked orally or in written form without a direct contact with the respondent or group of respondents

- The role of the archeologist consists in searching for information and possibilities which may be helpful in designing future changes. Useful methods in these terms are focus groups and intercepting clients.

- The interpreter explains clients' opinions and behaviors. Techniques which support this stage are sorting images, and voting with the use of dots.

- The role of the devil's advocate is to introduce chaos by questioning the accepted assumptions concerning the product, process, or service, searching for weak points and gaps. The most often used techniques include the 5 why and the cannonball.

The empathization stage is immensely important in terms of design thinking. The proposition of searching, gathering, explaining and ordering information presented above is possible to be used with smaller entities which either do not have the time, money, or will to carry out the research. The proposed techniques do not require large financial investments, do not take much time, are purposeful, and possible to be carried out taking advantage of creativity and an open mind. 


\section{Conclusions}

Summing up the thoughts included in this paper, it may be stated that the design thinking method constitutes a concept of designing focused on the person, which usage allows for (Jak wykorzystać..., 2015, p. 11):

- a deep understanding of clients' needs,

- offering products and services of a higher quality at lower costs,

- changes in the organization's culture, favorable for creating innovations,

- creating new development perspectives,

- increasing the efficiency of actions,

- improving production efficiency,

- a better communication with the client,

- a permanent improvement in terms of the relation of the client with the brand,

- distinguishing oneself from the competition,

- a coherence of the brand and offer.

Actions based on design thinking are characterized by (Jak wykorzystać..., 2015, p. 13):

1. Being oriented on the user - a striving to learn the needs and requirements of a client, determining his or her wishes constitutes the base for initiating design actions effects of which intend to satisfy the user and provide measurable advantages for him or her. It is also possible to introduce the client to the process of designing and co-creating common solutions.

2. An interdisciplinary character - the design thinking method requires knowledge and experience from various fields, that is because it allows to analyze the researched problem in many aspects and to develop optimal solutions.

3. Being focused on the future - it is impossible to rely only on verified solutions. What is needed is to look forward, foresee and forecast the changes concerning the requirements and expectations of clients, as well as to properly prepare for them.

4. Quickly testing solutions - creating prototypes at early stages has an impact on a faster verification of ideas and increases the efficiency of the process, at the same time reducing the costs related to implementing unnecessary or faulty solutions as well as those not generating an added value. 
5. Intense stages - the designing process consists in short but very intense stages, thanks to which it is possible to exchange knowledge, experiences, perform constant corrections, and perfect the undertaken actions.

The concept may be and is used in the sector of small and medium size enterprises. However, a mandatory condition is the absolute support and commitment (also financial) of the management, as well as its leadership. It impacts the improvement concerning the efficiency of innovative processes. It is a tool which does not require vast financial investments, but puts more emphasis on the creativity and ingenuity of employees who are not afraid of changes and search for all possible solutions to the analyzed problems, working in interdisciplinary teams taking advantage of design techniques.

\section{References}

Brown, T. (2008). Design Thinking. Harvard Business Review, 6 (86), 84-96.

Carlopio, J. (2009). Creating strategy by design. Design Principles and Practices: An International Journal, 3(5), 155-166.

Cooper, R., Junginger, S., Lockwood, T. (2010). Design thinking and design management: A research and practice perspective. In: T. Lockwood. Design thinking: Integrating innovation, customer experience andbrand value (pp. 57-63). New York: Allworth Press.

Junginger, S. (2009). Design in the Organization: Parts and Wholes. Research Design Journal, 23-29.

Lubińska, M., Więcka, A. (2015). Jak wykorzystać design w biznesie. Warszawa: PARP.

Lockwood, T. (2010). Design thinking: Integrating innovation, customer experience, and brand value. Boston, MA: Design Management Institute.

Martin, R. (2009). The design of business. Boston, MA: Harvard Business School Press.

Matthews, J., Wrigley, C. (2017). Design and Design Thinking in Business and Management Higher Education. Journal of Learning Design, 1(10), 41-54.

Plattner, H., Meinel, C., Leifer, L. (2011). Design Thinking: Understand - Improve - Apply. Heidelberg: Springer.

Poznańska, K. (1998). Uwarunkowania innowacji w matych i średnich przedsiębiorstwach. Warszawa: Dom Wydawniczy ABC.

Rudkin Ingle, B. (2015). Design Thinking dla przedsiębiorców i małych firm. Gliwice: Helion. 
Schmiedgen, J., Rhinow, H., Köppen, E., Meinel, Ch. (2015). Parts Without a Whole?: The Current State of Design Thinking Practice in Organizations. Technische Berichte Nr. 97, Potsdam: des Hasso-Plattner Instituts für Softwaresystemtechnik an der Universität Potsdam.

Wise, E., (2006). Understanding User-Driven Innovation. Copenhagen: Nordic Council of Ministers.

\section{ZASTOSOWANIE DESIGN THINKING W MAŁYCH I ŚREDNICH PRZEDSIĘBIORSTWACH}

\section{Streszczenie}

Design thinking jest jedną z nowoczesnych metod kreowania innowacyjnych rozwiązań wykorzystywaną przez duże i znane na całym świecie przedsiębiorstwa. Przyjętym celem badawczym było ustalenie, czy myślenie projektowe wykorzystywane jest również w sektorze małych i średnich przedsiębiorstw, a jeżeli tak to jaki jest zakres i możliwości stosowania. Badania oparto o analizę literatury polskiej i zagranicznej oraz o wyniki badań. Stwierdzono, iż podmioty gospodarcze funkcjonujące w sektorze MSP realizują koncepcję myślenia projektowego, a poprzez wykorzystanie kreatywności i technik design thinking mogą tworzyć innowacyjne rozwiązania.

Słowa kluczowe: innowacyjność, MSP, design thinking

Kod JEL: 031 